\title{
From Diaspora to Nationalism via Colonialism: The Jewish "Memory" Whitened, Israelized, Pinkwashed, and De-Queered
}

\section{Sahar Mandour}

\begin{abstract}
:
In this essay, I argue that the concept of queerness, defined as resisting static productions of knowledge and being, constitutes a threat to the monolithic narrative of Zionist Diasporic memory. As the Jewish memories were forced into one homogeneous linear narrative, the Israeli identity was whitewashed and branded; it differentiated itself from the Arabness of Mizrahi Jews, and served to suppress the histories of migrants and Palestinians alike in favor of absolute sovereignty and settler colonialism. This process, which I call dequeering memory, debilitates cross-temporal diasporic narratives, and celebrates a pinkwashed identity of white Jewishness.
\end{abstract}


"Queer not in the sense of a "gay" or same-sex loving identity waiting to be excavated from the ocean floor but as a praxis of resistance. Queer in the sense of marking disruption to the violence of normative order and powerfully so: connecting in ways that commodified flesh was never supposed to, loving your own kind when your kind was supposed to cease to exist, forging interpersonal connections that counteract imperial desires for Africans' living deaths."

(Tinsley, 2008:199) $)^{1}$

During the latest Israeli parliamentary elections (March 2015), the local debates and analysis emphasized a schism recurrently evoked by polls, between Ashkenazi (European) Jews and Mizrahi (Middle Eastern) Jews: Mizrahim votes granted victory to the Israeli Right wing, while the Ashkenazi-based Left votes failed to forward a "white" change. ${ }^{2}$ That schism dates back to the creation of the State of Israel in 1948, especially that Mizrahi Jews were made to choose between their Arabness and Jewishness. In fact, in the Zionist discourse, "Judeo-Arab culture was disdained as a sign of 'galut (diaspora)' - a negative term within EuroIsraeli Zionist discourse" (Shohat, 2006:205). Mizrahim evoked the diasporic in Israel; neither did they fit in nor did they feel at home in a country that never had a Mizrahi prime minister, and in an environment of European Jewish/secular nationalism. They had to constantly prove their Israeliness, while being marginalized economically and politically.

In the year 1948, the schism first occurred within the Mizrahi Jewish memory before it materialized in political dynamics with Ashkenazi. Eastern memories were expunged from a European official narrative, and the scattered experiences were unified in one memory narrative reciting past, present, and future. Described as "the blacks of Israel" (Shohat, 2006:222), Mizrahim had to distance themselves from Arab and Middle Eastern histories, which were judged inferior and in enmity with Israel. They also longed to prove their belonging to a linear storyline made out of a memory that was not theirs. Zionism, as a political ideology, weaved a fixed storyline for scattered amnesic and diasporic scenes, flattening time, geographies, and experiences, and incorporating that storyline into the Israeli identity. Moreover, I shall argue that these scattered diasporic memories constituted a queer threat to the Zionist narrative, which Zionism attempted to neutralize through instrumentalization and homogenization.

A tradition of queer and feminist-of-color critiques has articulated "queerness" as a political positionality; queerness, thus, does not solely designate same-sex behaviors or identities. For instance, Jin Haritaworn draws the parallels between "an 'LGBT community" and Benedict Anderson's "diasporic 'imagined community"' (2007:2.8). For the purpose of this essay, I will use "queering" as the process of making

\footnotetext{
${ }^{1}$ While this quote does not intend to equate the experiences of Mizrahim with that of Africans in the Middle Passage, it serves as an introduction to the uses of queerness as a politics of resistance and fluidity.

2 For an example of news coverage, check Heller's Huffington Post article "Ethnic Tensions Between Israeli Jews Fuel Netanyahu Victory."
} 
something queer, and the concept of queerness to designate a non-static state of being and knowledge production. Fatima El-Tayeb holds queerness to describe "a practice of identity (de)construction that results in a new type of diasporic consciousness neither grounded in ethnic identifications nor referencing a however mythical homeland" (2011:xxxvi). In fact, a diasporic situation is a critical state of constant motion, lived by groups that organically resist categorization. Forcing them into categories and producing static knowledge about them evoke an act of colonialism rather than a nationalist buildup. In this description, colonialism does not only designate the Palestinian ethnic cleansing and stolen land; rather, it names the process of engineering a unified Israeli identity out of the diasporic Jewish memory since 1948. The Israeli colonization of the Jewish diasporic memories served as the underlying justification in the colonization of Palestine's land, histories, and people. The "de-queering" process that took place fixated the cross-temporal diasporic Jewish narratives into a single truth over time and space. The histories of the Palestinian people were therefore suppressed and treated as "others" in favor of a colonizing version of the "promised" land.

The interruption of the Jewish diasporic narratives in the Israeli identity enables the treatment of Mizrahi Jews as internal subjects of colonization, and produces memory as static and linear. Eyal Sivan's documentary Izkor, Slaves of Memory (1990) and subsequent lectures discuss the Jewish-Israeli Memory and the process of fusing that engineered Memory into the children of Israel through the educational system. Using Avtar Brah's argument on Diaspora and Nationalism, and Puar's instrumentalization of gender in identity branding, this essay will argue, against the backdrop of another colonial venture, that the rigidity of the Zionism's Jewishness "de-queers" and brands the diasporic narrative at the expense of intersectional positionalities, such as the Mizrahim's.

In his "final reflections," Edward Said "predicted" in 1999 that the "demographic advantage for Jews [in Israel] would be lost by 2010" (Butler, 2012:212). Butler explains: "what he did not calculate was how the Law of Return would be invoked to increase Jewish immigration and how both new land confiscations and new boundaries would alter demography" (Butler, 2012:212). Whether or not the Exodus is considered the starting point of different Jewish diasporic narratives, the diasporic Jewish narrative adopted as the Israeli national memory linearly links Moses' escape from Egypt in 1446 BC to Hitler's European concentration camps in the Second World War (1939-1945). In the later stage of narration, the historical Jewish Diaspora meets its equally historical end with the "return" to "the homeland of all Jews," Israel (Shohat, 1988:1), and the "routes" that led back to the "roots" (Gilroy in Brah, 1996:192). The Law of Return was granted to all Jews, and Israel became "a centre, a locus, a 'home' from where the dispersion occurs" (Brah, 1996:181). Embedded in victimhood, this representation benefits from a constructed trans-generational diasporic fear that instrumentalizes the subsequent fear of historical repetition. Indeed, Israeli settler colonialism showcases the repetition of a pre-historic exodus and modern time holocaust as to legitimize a colonial narrative, thus confining the diasporic memori(es) to a predefined identity. Endowed with the firmness of birthright, such an identity remains far from its queered pasts and presents: Israeli Jewishness stagnates in a unidirectional 
identity of ethnic and racial belonging, and works towards dismantling and oppressing the production of difference.

Israeli demographics were never left uncontrolled in the State of Israel. The birth of a Jewish nation-state engendered that of an Israeli citizenship. From the day of its creation in 1948, the State engineered its identity as well as the body of its citizenship on the heavy lines of class, race, but also gender. Even before the State was created, Zionism's "early days" envisaged the necessary economic structure "to downplay Israel's 'Easterness' as well as its 'Third Worldness'” (Shohat, 1988:2). The mythological aspect of the Jewish Diaspora underwent a literal materialization, while the scattered histories and geographies of diasporic Jewishness were colonized by linear Western discourse: "Zionism posited itself as an extension of Europe in the Middle East, carrying its Enlightenment banner of the civilizing mission" (Shohat, 2006:219). Reproducing the dynamics of Orientalism and European colonialism, the Israeli identity essentialized a Jewish memory and colonized both its diasporic queerness, and the land and people of Palestine. Embodied by migration, Arabness, and blackness, cross-temporal diasporic queerness is neutralized in favor of an instrumentalized narrative of return and right. Though judged as "savages" (Shohat, 1988:5), Oriental and African Jews "were perceived as a source of cheap labor that had to be maneuvered into immigrating to Palestine" (Shohat, 1988:13). To reduce the gap between Europeanness and "its" others within the nationalist context of building a State (Shohat, 1988:3), a self-directed colonial mission civilisatrice ${ }^{3}$ (civilizing mission) was launched, deepening the schism that still persists today (Said, 1978:169-263). Shohat has demonstrated the ways in which Mizrahim were considered galuti or "Diasporic Jews," with no histories and belongings (Shohat, 2006:217-219). The monolithic memory of the Israeli narrative absorbs the many historiographies that originate from Asian and African Diasporas and migrations, thus limiting the migrants' access to their own knowledge and histories (Shohat, 1988:8). In fact, not only does the following historicization explain the basis of the Zionist thought, but it also reveals the conscious battle of the Israeli identity against the diasporic elements evoked by Eastern Jewishness, as well as the excessive and venerated militarization of a "strong" nuclear State.

Duplicating the Eurocentric vision of the colonized world in the post-WWII era, the dynamics of internal racism(s) were applied in Israel. They followed an ideological balance that allowed and still allows the "first world" economy to benefit from so-called Oriental (Jewish) cheap labor, transposing a unifying identity to history. Emphasized and invested in the display of the Israeli identity, Jewish essence constitutes one of the fundamental principles of Zionism. Despite internal Jewish racisms, this essence legitimizes the "all" in Israel's "homeland of all Jews" founding narrative; it may also be instrumentalized to immune the identity against the remains and possibilities of diasporic queering. The queer potential of migrants' imported histories could constitute a threat to the static knowledge production of the Zionist state and narrative, especially if put in dialogical conversation with those of the Palestinian people. According to Shohat, the monolithic

\footnotetext{
${ }^{3}$ Golda Meir, who served as the Israeli Prime Minister from 1969 to 1974, wondered if Israelis would be "able to elevate these immigrants to a suitable level of civilization" (Meir in Shohat, 1988:5).
} 
experience of being Jewish does not tolerate any "overlappings with other religious and ethnic communities;" in fact, being Jewish presupposes giving up any other culture they initially belonged to (2006:215). However, the identity crafted for this community in modern-day Europe needed not to be swallowed by religion, despite its excessive religious essentialism - the Torah is a central reference on all imaginable levels, even in this army. Adopted by Zionism, secularism is an Enlightenment illustration of European superiority as well. Here too, post-Enlightenment Europe bestowed on Zionism the religious balance of its modernity: "a new, unified Europe characterized by a tolerant secularism rooted in Christian principles" inspired Zionism to offer its new and unified project a modern Israeli secularism rooted in Judaism (El-Tayeb, 2011:81-82).

The supposedly secular Israeli identity of the Jewish people can be redefined by Brah's racialization of religion; the "colonial discourses and political practices" (1996:169) significantly allow Zionism to restrict nationalism to a religious adherence, while making a claim of secularism. Because of its secular framing, the monolithic diasporic narrative had exacerbated internal tensions among Jews. However, as Shohat notes, Zionism was legitimized and made normative post-holocaust (Shohat et. al, 2013). Within secularism, the Israeli identity benefits from the possibility to actualize mythology, materialize faith and beliefs, and govern a queered diasporic fear. In the Euro-American narratives, diasporas and immigration are perceived "as threats to the integrity of a nation" (Tinsley, 2008:193). The same can be said of the Zionist articulation of Jewish identity in relation to diaspora, with the difference that the diasporic space is produced as a "queer" threat that disrupts the linearity of the memory narrative. A queered perspective of diaspora would, in Haritaworn's words, "be a means of re-homing us into our imagined diasporic communities and fulfilling our nostalgic longings for belonging" (2007:5.2). In other words, it would resurface "the shared experience of multiple, contradictory positionalities" (El-Tayeb, 2011:xxxvi), threatening to disintegrate the hierarchized, static structure of Jewishness within the Israeli nation-state.

As a matter of fact, Israel refuses to be a diaspora space, and avoids it by colonizing the discourse on diaspora (Brah, 1991:181). Jewish nationalism stands up to the concept of diaspora, knowing that the latter "offers a critique of discourses of fixed origins, while taking account of a homing desire which is not the same thing as desire for a "homeland"' (Brah, 1996:180). The queered diaspora and the hyphenated identities are fixed in specific axes of date, time, and identity space (Spivak, 2008:220): "Arab-Jews became Israelis. All of this happened virtually overnight" (Shohat et. al, 2013). Becoming Israelis, as a matter of fact, was not equated with becoming Euro-white; rather, it meant abiding by a Euro-white definition of Jewishness and a Euro-white framing of the memory, while applying the Euro-racisms associated with class, race, and gender.

As a precursor, the Euro-American colonial discourse proved useful in defining the Israeli identity, which acquired consistency across time. The homonormativity ${ }^{4}$ of the LGBT rights discourse is of no exception to the de-queering of discourses: it departs from the Euro-American model, which locates "the Western LGBT

\footnotetext{
${ }^{4}$ Lisa Duggan defines homonormativity as "a politics that does not contest dominant heteronormative assumptions and institutions but upholds and sustains them while promising the possibility of a demobilized gay constituency and a privatized, depoliticized gay culture anchored in domesticity and consumption" (2002:179).
} 
community" in "the role of civilizer" and "queer Muslims" as "products of a culture that is fundamentally inferior to the secular West" (El-Tayeb, 2011:120). Non-Westerns are therefore produced "as by default homophobic and heterosexual," in opposition to whiteness (El-Tayeb, 2011:120). As a fundamental stage of identity engineering, Israeli identity adopted what Jasbir Puar has called homonationalism ${ }^{5}$ since the 1990 s, and rebranded itself to fit the "Pink" colonial discourse of the era by promoting itself as gay-friendly and liberal.

However, before the Pink, a whitening process that mirrors the Euro-American dichotomy of whiteness vs. communities of color had already taken place. Pre-pink whitewashing set the demographic ground for its new, superior, and unified Jewish memory; a narrative on which a nation, an Identity, and a population "'ingather[ed] from the four corners of the earth'" (Shohat, 1988:13). Indeed, by unifying diasporic narratives and grounding them at "home", the Jewish memory existed as an accomplished experience available for drawing lessons and framing fears. Branded, Zionism presented the nationalist narrative of the Jewish memory as a terminal to that long dating, continuous, and proliferated diasporic motion: Israeli Identity replaced queered Jewish identities via nationalism: "The notion of the New Jew was influenced by the Jugendkultur, or youth movement in German (...); the hero would often be blonde, blue-eyed, or at least light skinned, and of course never graced with the stereotypical hooked nose" (Shohat et. al, 2013). An interesting figure is drawn by Shohat in this regard: she centers the "New Jew" in Israel within one triangulation of identities (Jewish, Arab, and Western), intersected by another triangulation of times (historical, sacred, and modern). The de-Semitization that falls under hegemonic Western logic (Shohat et. al, 2013) is first and foremost a process of de-queering the "New Jew," who becomes tokenized and neutralized in the binary Zionist discourse of white vs. Mizrahi, and pink vs. backwards.

As part of their whitewashing "branding", Israel enforced a process of cleansing the Arabness of Mizrahi, thus "saving" them from their Oriental origins and belonging (Shohat, 2006:225). As a nationalistic effort of Westernization, Middle Easternness and Arabness were repressed by the establishment in order to differentiate between Jewishness as belonging to the West, and Arabness as confined to the East (Shohat, 2006:225). Not only did Zionism fix an origin for that memory, but it also engineered its specificities throughout the years and "within this nexus of history and economy" (Puar, 2013:337). Quoting Goethe on memory, the Israeli scholar and acclaimed filmmaker Sivan affirms: "When I hear the word memory, I immediately wonder what was forgotten" (Sivan, 2012).

In his award-winning documentary film Izkor, Slaves of Memory, Sivan approaches the fundament of the process of Israelization of the Jewish citizenry, set firmly in the educational system. Every April, and over the course of 30 days, citizens of Israel are required to commemorate four almost-sacred Nationalist events: the Passover (evoking the exodus from Egypt, and celebrating the freedom of Jewish slaves), the Holocaust Remembrance Day (evoking WWII), the Fallen Soldiers and victims of Terrorism Remembrance Day (evoking the Post 1948 wars against the Arabs, namely the 1973 war with Egypt), and the Independence Day (which

\footnotetext{
5 Jasbir Puar elaborates on homonationalism in her book Terrorist Assemblages: Homonationalism in Queer Times.
} 
marks the Nakba Day, on the Palestinian and Arab agenda). April "season" has a feel of reinforcing memory. At school, and under the firm supervision of their fervent patriotic teachers, Mizrahim and Sephardim kids are made to memorize the memory narrative, participate in school and State events of commemoration, and engage in representing that narrative.

In Sivan's documentary, a child of Moroccan descent literally identifies with the Holocaust: "it is as if it has happened to me." He then adds: "there are only bad things in history." No Jew wants to go back there; no Jew would even risk an action that may bring "us" (them) back there. Most of the kids in the documentary show an emotionally charged enthusiasm to join the army: "I owe it to my country," says a young girl. Within the Memory narrative, the Israeli soldiers who died in wars against Arab armies are exonerated and commemorated as victims: an 18-year-old soldier who died during the 1973 war with Egypt "got hit by an Egyptian missile," thus silencing the context of war. Founded on victimhood, Israel's linear narrative allows access to systematic exoneration, as Sivan notices in his documentary. With a conscious, methodological, and disciplinarian State effort, the Israeli Identity fights the queerness of the Jewish diaspora, that is, the unstable "otherness" of the non-white migrants.

In fact, every April denotes the anti-queering effort of stabilizing the Israeli identity. Twice during that month, the People of Israel stand still for a minute one morning, then two minutes the next morning, to the sound of a siren that reverberates across the Land to remember the dead. Even though Spivak asserts that "there is no continuous line from then to now" (2008: 211), that siren instrumentalizes the old fear of linear repetition. Wherever the citizens are (in their cars, at their jobs, at home ...), no matter how the contexts of their lives differ (Palestinian citizens of Israel, Arab-Jews who did not suffer a Holocaust ...), they stand still, witnessing that moment of silence as the embodiment of the Israeli identity. The sound of the siren serves to "unify" them. More, it seeks to prevail over and homogenize divergences and differences by fixing the present moment in a specific history and memory. Exodus, holocaust, the present and the future are all condensed in one frozen, anti-diasporic space/time. That spectacular moment also fuses fear and victimhood: "so sleep now my child, / you'll see that one day we won't be afraid," says the song "Sleep, My Child," performed at the Remembrance Day ceremony (Hermoni and Lebel, 2011:477).

Israeli nationalism is rooted in a narrative of victimhood that acts as a lighthouse, guiding the People to safety: "the idea of the unique, common victimization of all Jews at all times provides a crucial underpinning of official Israeli discourse" (Shohat, 2006:214). Not only does victimhood ensure a higher commitment to citizenship, but it mostly suggests that the memory can be instrumentalized as a "vaccine" that prevents victims from ever becoming perpetrators. In a lecture he gave in Sarajevo, Sivan argues for a possible use of the memory as "a tool of crime" (Sivan, 2012). Indeed, the Israelization of the memory goes hand in hand with militarization: the venerated soldiers of the State are the protectors of the population from the repetition of atrocities. Instead, the lessons drawn from that memory are repeated in the Israeli space endlessly. While one child describes the siren as "a child crying for help," another explains that he stands still and silent to the sound of the siren "for a kid that died for my country" (Sivan 1990). 
Both the army and the Israeli identity are subjected to a recurrent process of exoneration and celebration, or more accurately "branding" within Israel. The excessive rooting of Israeli nationalism in the memory alone could neither silence the growing global criticism of a settler colonial existence (soaked in criminality), nor fulfill the requirement for a Western neoliberal/neocolonial updated agenda. In the late 1990s, the Israeli identity was "PinkWashed" to re-"brand Israel" by "tapping into the discursive and structural circuits produced by U.S. and European crusades' against Islam, but also towards the contemporary phase of the capitalist globalized economy" (Puar, 2013:337). Another top-down engineering of the Israeli identity made it adhere to the criteria of the new Western millennium: "targeting global cities such as New York, Toronto, and London, the 'Brand Israel' campaign has used events such as film festivals to promote its image as cultured and modern" (Puar, 2011:137-138).

The "New" and unified Jewish identity called for a colorful "Branding": the Pink Jew came to represent an updated, gay-friendly version of the White Jew. The Pink Jew comes closest to the liberal Western discourse pushing for "gay" rights, and constructed in opposition to its external and internal diasporic "others". Launched in January 2013, the Israeli Ministry of Foreign Affairs began the "creative" project "Brand Israel," targeting the image, identity, and attractiveness of Israel since 2006. Under the title "Rebranding Israel: History out, creativity and innovation in," Haaretz contextualized the news in the launch coverage as such: "the international media usually mentions the country in the context of war, missiles and terrorism. Israel ranked 27th in the Country Brand Index in 2012, a slight improvement from 28th place in 2011 and 30th in 2010" (Tucker, 2013). According to Puar, "one of the most prominent features of the 'Brand Israel' campaign is the marketing of a modern Israel as a gay-friendly Israel" (2011:137-138). Postcolonial scholars and activists focused their criticism on Pinkwashing's attempt to "reframe the occupation of Palestine in terms of civilizational narratives measured by (sexual) modernity" (Puar, 2013:337). However, the Pinkwashing process had other colonial missions to accomplish as well: it allowed modern Israel to control nonheteronormativity by firmly defining it within "the conceptual frame of homonationalism" (Puar, 2013:336). Pinkwashing incarcerated queerness, but celebrated fixed identity discourses: the branding campaign claims that "only in Israel" can an officer be openly Gay/Trans, following a tradition of disciplining queerness through the military.

The "New Jew" called for "New" traits to fit post-WWII modernity. In harmony with their predecessors, the supposedly "queer" young men and women shown in the campaign and celebrating the birth of the New Gay Jews came out of the Israeli closet "physically strong with blond hair and blue eyes; healthy looking and cleansed of all 'Jewish inferiority complexes'" (Shohat, 2006:217-219). While the Pink Jew is an updated version of the White Jew, it does not lose its whiteness. Therefore, in the context of Pinkwashing and Israel, pink becomes a shade of whiteness. But what does that make of the Mizrahi Jews, and are they included in the whiteness of the "New Jew?" 
In concordance with Puar's reading of Islam in the new homonationalist world order, Manuela Boatcă reminds us that "the 'Islamic threat' replaced the Communist one in the hegemonic Occidental imaginary" (2013). Mizrahi Jews, though historically and geographically "closer" to Palestinian land, are the less-flattering version of the "New Jew." Their "Arabness" is considered to be "a product of millennial cohabitation" and "a Diasporic stain to be 'cleansed' through assimilation" (Shohat, 1999:6). While the standing of downright "Other" is reserved to Palestinians - the direct subjects of colonization, Mizrahi Jews are constructed as the "incomplete Self" of the Israeli identity (Boatcă, 2013). Since they cannot be separated from the Jewish diaspora at large, they are treated as internal subjects of colonization. Their non-whiteness and historical "Arabness" brand them as a potential queer threat to the Jewish linear memory: not only are they symbols of difference in their ethnic belonging and non-linear histories, but they also challenge the static fixation of identity, whether sexual or otherwise. As a response, the shaded washing and branding normalize their experiences and blend them with the linearity of the Zionist narrative, while maintaining their status as "insufficiently" Jewish (Shohat, 1999:8) due to their association with Arabs in a perpetual cycle of exceptionalism. Opening access to diasporic queering would therefore question the viability of a fixed "colonized" identity, as it was demonstrated by recent political mobilization against pinkwashing and ethnic cleansing. Israel, therefore, is one extreme example of the many de-queering processes that fixate diasporic memories and narratives to achieve military and political sovereignty.

Across its 67 years of state sovereignty, the nationalization of "whitened" Jewish diasporic memories reclaimed a Westernness that opposes Arabness and Easternness, and pinkwashed militarization within the axes of fear and victimhood. A diasporic situation, commonly acknowledged as "the diaspora par excellence" and the "ideal type" (Safra, 1991:84), is colonized by a linear narrative and channeled towards nationalism, instead of acting as a queered movement challenging it. Zionism fights against signs of queerness within the Israeli identity and memory. However, "memory is the interaction between forgetting and remembering" (Sivan, 2012), where multiple memories imply a dynamic openness to queerness.

A cross-century historicization allows for a contextualized perception of the Israeli era within broader Jewish diasporic narratives. In fact, Jewish narratives and memories are not limited to Israel; yet, imagining a contemporary Jewish narrative completely detached from Israel, whether through criticism or support, is quite impossible. From an insider's view, Israel is an effort to end diverse diasporic narratives. However, a crosstemporal diasporic perspective would read Israel as another "experience" de-queering Jewish diasporic memories. Indeed, Israel's colonial resistance to queerness is a source of many critical interventions in an ongoing narrative that occurs alongside mythological, historic, socio-economic, and political realities, as well as Jewish and Israeli internal and external conversations.

Shohat notices a penchant towards producing new types of Oriental music among Arab Jews. Once investigated, she conceptualizes it as a "desire for 'return of the Diaspora' [that] ironically evokes an attitude 
Kohl 1.1

I 51 that reverses the biblical expression of nostalgia for Zion. Now it becomes: "By the waters of Zion, where we sat down, and there we wept, when we remembered Babylon" (Shohat, 2006:226). After all, linearity challenges the mechanisms of the memory, the narratives of history, and the life experiences of humans, whether in diaspora or in nationalism. 


\section{References}

Boatcă, Manuela (2013) "Multiple Europes and the Politics of Difference Within." Worlds and Knowledges Otherwise $\quad 3.3 . \quad$ Available at: https://globalstudies.trinity.duke.edu/wpcontent/themes/cgsh/materials/WKO/v3d3_Boatca2.pdf

Brah, Avtar (1996) "Diaspora, Border and Transnational Identities." Cartographies of Diaspora. Contesting Identities. London, New York: Routledge S.

Butler, Judith (2004) "The Charge of Anti-Semitism: Jews, Israel, and The risks of Public Critique." Precarious Life: The Powers of Mourning and Violence. London, New York: Verso

Butler, Judith (2012) "What shall we do without exile?" Parting Ways. Jewishness and the Critique of Zionism. New York: Columbia University

Duggan, Lisa (2002) The Incredible Shrinking Public: Sexual Politics and the Decline of Democracy. Boston: Beacon Press

El-Tayeb, Fatima (2011) European Others. Queering Ethnicity in Postnational Europe. Minneapolis, London: University of Minnesota

Haritaworn, Jin (2007) "Shifting Positionalities: Empirical Reflections on a Queer/Trans of Colour Methodology." Sociological Research Online 13.1. Available at: http://www.socresonline.org.uk/13/1/13.html

Heller, Aron (2015) "Ethnic Tensions Between Israeli Jews Fuel Netanyahu Victory." The Associated Press, published in The Huffington Post, 04 April 2015. Available at: http://www.huffingtonpost.com/2015/04/04/israel-ethnic-tensions_n_7003404.html

Hermoni, Gal \& Lebel, Udi (2012) "Politicizing Memory." Cultural Studies 26(4): pp. 469-491. Available at: http://dx.doi.org/10.1080/09502386.2011.622779

Izkor: Slaves of Memory (1991) Directed by Eyal Sivan. Documentary film, 97 minutes, Israel. Paris: Ima Production

Puar, Jasbir K. (2011) "Citation and Censorship: The Politics of Talking About the Sexual Politics of Israel." Feminist Legal Studies 19: pp. 133-142

--.. (2007) Terrorist Assemblages: Homonationalism in Queer Times. Durham NC: Duke University Press

---. (2013) "Rethinking Homonationalism." International Journal of Middle East Studies 45: pp. 336-339

Said, Edward W. (1978) Orientalism, 2003. London: Penguin Books.

Safran, William (1991) "Diasporas in Modern Societies: Myths of homeland and Return." Diaspora: A Journal of Transnational Studies 1(1): pp. 83-99

SaraJevo Film Festival (2012) "Discussing the Present, Shaping the Future - An Encounter with Eyal Sivan," published on 14 November 2012. Available at: https://www.youtube.com/watch?v=ZaEPU89fexM

Shohat, Ella, Boatcă, Manuela, \& Costa, Sergio (2013) "Bodies and Borders: An Interview with Ella Shohat." Jadaliyya. Available at: http://www.jadaliyya.com/pages/index/15203/bodies-and-borders_aninterview-with-ella-shohat

Shohat, Ella (1988) "Sephardim in Israel: Zionism from the Standpoint of Its Jewish Victims." Social Text 19/20: pp. 1-35. Duke University Press 
Kohl 1.1

| 53 ---. (2006) "Taboo Memories, Diasporic Visions: Columbus, Palestine, and Arab-Jews." Taboo Memories, Diasporic Voices. Durham and London: Duke University Press

---. (1999) "The Invention of the Mizrahim." Journal of Palestine Studies 29.1: 5-20

Spivak, Gayatri Chakravorty (2008) "Our Asias 2001 - How to Be a Continentalist." Other Asias. Malden, MA, Oxford: Blackwell Pub. 209-238

Tinsley, Omise'eke Natasha (2008) "Black Atlantic, Queer Atlantic: Queer Imaginings of the Middle Passage." GLQ: A Journal of Lesbian and Gay Studies 14.2-3: 191-215. Duke University Press

Tucker, Nati (2013) "Rebranding Israel: History out, creativity and innovation in." Haaretz, 6 January 2013. Available at: http://www.haaretz.com/news/features/rebranding-israel-history-out-creativity-andinnovation-in.premium-1.492147 